\title{
Assessment of economic vulnerability of the households of floodplain wetland fishermen
}

\author{
ARUN PANDIT, D. K. MEENA, VIKASH KUMAR, ANJANA EKKA AND U. K. SARKAR \\ ICAR-Central Inland Fisheries Research Institute, Barrackpore, Kolkata - 700 120, India \\ e-mail: arunpandit74@gmail.com
}

\begin{abstract}
Fishermen communities, in general and inland fishermen in particular are one of the most marginalised and vulnerable group in India with extreme poverty and very low economic base. The present study was conducted to investigate the economic vulnerability of the fishermen households of two beels (floodplain wetlands) in West Bengal (Kholshi and Akaipur) and one beel in Assam (Deepor) based on a sample of 185 fishermen households. By employing the methodology developed by Bene (2009) it was found that the average vulnerability scores were $0.21,0.14$ and 0.33 for Kholsi, Akaipur and Deepor beels, respectively on a scale of 0 to 1 . The study showed that in flood plain wetlands with well managed cooperative society, optimum and scientific stocking, income diversification and participatory management, agricultural land holdings can significantly lower economic vulnerability of the fishermen households. The study suggests the Government to facilitate creation of supplementary income generating opportunities and integrated agricultural activities in the vicinity of the wetlands. There is potential for developing eco-tourism with suitable infrastructure in beels like Deepor, which may help to provide supplementary employment to fishermen.
\end{abstract}

Keywords: Assam, Economic vulnerability, Fishermen, Flood plain wetland, West Bengal

Wetlands are natural resources having immense ecological and economic importance and play vital role in groundwater recharging, flood control, shoreline stabilisation, sediment retention, retention of nutrients, biodiversity conservation and biomass production. Wetland ecosystems are rich in fish biodiversity. Wetlands are home to $40 \%$ (approximately 8500 species) of fish species in the world (Parish and Looi, 1999). However, due to siltation, loss of river connectivity, conversion to arable land, dumping of refuse, nutrient enrichment through sewage effluents and agricultural fertilisers, wetlands are degrading day by day which leads to destruction of aquatic resources and fisheries resources in particular. As a result, it becomes more difficult for fishes to find ideal habitats and consequently the fishermen dependent on these ecosystems find it difficult to sustain their livelihood.

In India fishermen communities are highly marginalised group of people since ages. Traditionally, fishermen especially the inland fishermen are extremely poor with very low economic base. Climate change is an added threat to existing vulnerabilities (UNPEI, 2003). The extent of impact of any external shock including climate change on any community will necessarily depend on the degree of vulnerability. Studies have shown that vulnerability is the central element of poverty (Chambers, 1989; Khan, 1998; Narayan et al., 2000; World Bank, 2000;
Prowse, 2003) and it is also true in the other way round i.e., poverty is a factor for vulnerability. Although studies have been conducted on vulnerability of ecosystems like reservoir (Chang et al., 2008); river basin (Palaniasamy et al., 2010), beach tourism (Sabine, 2010) and vulnerability to specific threats like HIV-AIDS (Nagoli et al., 2010), epidemic malaria (Wandiga et al., 2010), only a few studies (Bene, 2009) are available regarding assessment of economic vulnerability of fishermen communities. Economic vulnerability studies help researchers and policy makers to identify households having high degree of vulnerability which need immediate attention for implementing adaptation programmes.

The present study was conducted to investigate the economic vulnerability of the fishermen households in two flood plain wetlands in West Bengal (Kholshi and Akaipur) and one wetland in Assam (Deepor). One hundred eighty five fishermen households (100 from West Bengal and 85 from Assam) were interviewed for the study during the period 2013-2015. Data were collected on structured schedules on various socio-economic aspects viz., personal data of fishermen, household information, education status, economic activities, income sources and expenditure data.

The model developed by Bene (2009) was employed for assessing the economic vulnerability. The model uses 
cross section data, which is very useful in Indian context as primary data on socio-economic variables are rarely available. The model is as follows:

$$
\begin{gathered}
\mathrm{V}_{\mathrm{ig}}=\mathrm{CV}_{\mathrm{g}} \text { Dep }_{\mathrm{ia}} \frac{1}{\operatorname{Div}_{\mathrm{i}}} \operatorname{Pov}_{\mathrm{i}} \\
\text { where, } \text { Div }_{\mathrm{i}}=\mathrm{A}_{\mathrm{i}}\left(1-\text { Dep }_{\mathrm{ia}}\right)+\sqrt{\operatorname{Sub}_{\mathrm{i}}+1} \\
\operatorname{Pov}_{\mathrm{i}}=\sqrt{\frac{\bar{Z}}{Z_{\mathrm{i}}}}
\end{gathered}
$$

where $\mathrm{V}_{\mathrm{ig}}$ is the vulnerability index, $\mathrm{CV}_{\mathrm{g}}$ is the coefficient of variation (CV) of household's income belonging to the same group $\mathrm{g}$ and $\mathrm{Dep}_{\mathrm{ia}}$ is the proportion of total cash income of the household $\mathrm{i}$ derived from the main activity $a . A_{i}$ is the total number of activities in which the household $\mathrm{i}$ is engaged, $\mathrm{Sub}_{\mathrm{i}}$ is the number of subsistence activities amongst this total number. $\bar{Z}$ is the poverty line and $Z_{i}$ is the daily cash income of the household $i$. The different evidences confirm that this new vulnerability index can provide a simple but meaningful methodology to analyse economic vulnerability.

Out of the two selected beels of West Bengal, Kholsi is a seasonally open and Akaipur is a closed beel. The Kholsi Beel is in Nadia District and Akaipur is in North 24 Parganas District of West Bengal. Fisheries of the two beels were managed by Kholsi Udbastu Matsajibi Samabay Samiti Ltd. (KUMSSL) and Akaipur Dwarbasini Matsajibi Samabay Samiti Ltd. (ADMSSL), respectively. The registered members are 317 and 80 respectively. On the other hand, the Deepor Beel is the only Ramsar site in Assam. It is located to the south-west of the Guwahati City. The beel provides a means of livelihood to a number of local families. There are 9 villages in the vicinity of the beel and around 850 fisher households are involved in fishing. The wetland as core area covers 414 ha. The fishermen have formed the Deepor Beel Panchpara Cooperative Society Ltd. (1976-77) for managing the beel.

Table 1 shows that the average vulnerability scores were $0.21,0.14$ and 0.33 for Kholsi, Akaipur and Deepor

Table 1. Distribution of households according to vulnerability index ( $\%$ of fishers' households)

\begin{tabular}{llll}
\hline $\begin{array}{l}\text { Vulnerability } \\
\text { index }\end{array}$ & Kholsi & Akaipur & Deepor \\
\hline$<0.10$ & 26.53 & 51.06 & 18.64 \\
0.10 to 0.20 & 32.65 & 23.40 & 25.42 \\
0.20 to 0.30 & 12.24 & 19.15 & 8.47 \\
0.30 to 0.40 & 18.37 & 4.26 & 11.86 \\
0.40 to 0.50 & 6.12 & 2.13 & 11.86 \\
$>0.50$ & 4.08 & - & 23.73 \\
Average & 0.212 & 0.140 & 0.33 \\
\hline
\end{tabular}

beels, respectively. In Akaipur, the vulnerability is lowest and in Deepor Beel it was highest. Vulnerability of majority of the households in Akaipur was less than 0.30 . Fisheries was well managed by the society of this beel, which contributed to lower vulnerability. In Kholsi, the majority of households were in 0.10 to 0.40 category. In Deepor, sizeable households were in $>0.50$ category, but in Akaipur, no household was found to be in 0.50 category. In general, fishermen earned higher income than the state poverty line in Akaipur which helps to reduce the vulnerability. The study further showed that income diversification can be a factor to lower economic vulnerability.

Detailed study in Akaipur Beel showed that the Cooperative Society in Akaipur is well managed. The Managing Committee comprises Chairman, Vice Chairman, Secretary, Assistant Secretary and Cashier. There are 5 Directors, including two Government nominees (Fisheries extension officer and one Panchayat representative). They all are elected in every five years. There are 80 members and the society employs one Manager (salary ₹5200 per month) and 4-5 chowkidars. Society allotted 10 katha ( $0.067 \mathrm{ha})$ of land to most of the members. The society was found to be well managed and the management is more 'participatory'. Moreover, optimum and scientific stocking was done in this beel. Fishermen of this beel earned higher income than their counterpart of Kholsi or Deepor beels. Moreover, the Akaipur fishermen had more income diversification options and all these factors together, helped to lower the economic vulnerability index.

An attempt was also made to identify the factors affecting the economic vulnerability indices. A multiple linear regression was fitted using vulnerability index as dependent variable as explained below:

$$
\mathrm{Y}=\mathrm{a}+\mathrm{b}_{1} \mathrm{X}_{1}+\mathrm{b}_{2} \mathrm{X}_{2}+\mathrm{b}_{3} \mathrm{X}_{3}+\mathrm{b}_{4} \mathrm{X}_{4}+\mathrm{u}
$$

where, $\mathrm{Y}=$ Economic vulnerability index, $\mathrm{a}=$ Constant term, $\mathrm{b}_{\mathrm{i}}$ 's $=$ Regression coefficients, $\mathrm{X}_{1}=$ Years of schooling

$\mathrm{X}_{2}=$ Operational holding (ha), $\mathrm{X}_{3}=$ Number of subsistence activities, $X_{4}=$ Family size, $u=$ Random term, $N W \sim\left(0, \sigma_{\mathrm{e}}^{2}\right)$.

Regression analysis shows that out of the four factors considered, operational holding (agricultural land holding) and the number of subsistence activities significantly lowered the economic vulnerability (Table 2). Operational holdings provide the fishers opportunity to grow crops or vegetables which provide food and some extra income to the family. Subsistence activities are also extremely important to lower the vulnerability. When more subsistence activities are 
Table 2. Factors affecting vulnerability indices

\begin{tabular}{llll}
\hline Variable & Coefficients & $\begin{array}{l}\text { Standard } \\
\text { error }\end{array}$ & p-value \\
\hline Intercept & 0.261369 & 0.03846 & $1.091 \mathrm{E}-09$ \\
Years of schooling & -0.00447 & 0.002779 & 0.110808347 \\
Operational holding & -0.03177 & 0.010991 & 0.00480773 \\
Subsistence activities & -0.06598 & 0.0138 & $6.685 \mathrm{E}-06$ \\
Family size & 0.012019 & 0.007447 & 0.110009674
\end{tabular}

$\mathrm{R}^{2}=0.457, \mathrm{n}=96$

available, if one activity fails others will be there to compensate the loss. Through simulation study, Bene (2009) also showed that complementary activities together with subsistence activities are extremely important for lowering economic vulnerability. Other two factors viz., years of schooling and family size were found to have negative and positive impact respectively on vulnerability, but they were not much significant.

In India, fishermen communities in general and inland fishermen in particular are one of the most marginalised and vulnerable group of people with extreme poverty and very low economic base. Presence of well managed cooperative society, optimum and scientific stocking, income diversification, participatory management and operational holdings were found to significantly lower the economic vulnerability of fishermen households in flood plain wetlands. Therefore, Governments need to facilitate supplementary income generating opportunities. The State Fisheries Departments could impress upon the fishermen to go for integrated agricultural activities in the vicinity of the wetlands. The Deepor Beel is a perennial freshwater wetland, located in the vicinity of Guwahati City. The beel harbours the largest concentration of aquatic birds in Assam. The neighbouring hills and forests are home for many endangered and rare species of animals and insects. The beel also has high tourism potential and hence there is scope for developing eo-tourism in the beel with suitable infrastructure which would help to provide supplementary employment to fishermen.

\section{Acknowledgements}

The authors are thankful to ICAR, New Delhi for financial support, Director ICAR-CIFRI for providing necessary facilities to carry out the research work, Dr. B. K. Bhattacharjya, Head Guwahati Regional Research Centre of ICAR-CIFRI and all the fishermen respondents for their help during data collection.

\section{References}

Bene, C. 2009. Are fishers poor or vulnerable? Assessing economic vulnerability in small-scale fishing communities, J. Dev. Stud., 45: 6, 911-933, DOI: 10.1080/00220380902807395.
Chambers, R. 1989. Vulnerability, coping and policy. IDS Bulletin, 20(2): 1-7.

Chang Chia Ling, Pei Te Chiueh and Yen Shun Peng 2008. A vulnerability analysis in the Fei-tsui reservoir watershed in Taiwan. Environ. Monit. Assess., 143: 9-14. DOI 10.1007/s10 661-007-9943-4

Khan, A. R. 1998. Poverty in China in the period of globalisation: new evidence on trend and pattern International Labour Office, Development Policies Department, Discussion paper 22, Geneva., 58 pp.

Nagoli, J., Holvoet, K. and Remme, M. 2010. HIV and AIDS vulnerability in fishing communities in Mangochi District, Malawi, African J. AIDS Res., 9(1): 71-80

Narayan, D., Chambers, R., Shah, M. and Petesch, P. 2000. Voices of the poor, crying out for change. Oxford University Press for the World Bank, 314 pp.

Palanisami, K., Kakumanu, K. R., Udaya Sekhar, N., Ranganathan, C. R. and Barton David, N. 2010. Impacts of climate change on agricultural production: Vulnerability and adaptation in the Godavari River Basin, India. Climawater Report No. 4. December, 2010

Parish, F. and Looi, C. C. 1999. Wetlands, biodiversity and climate change. Opinions and needs for enhanced linkage between the Ramsar conventions on wetland, Global Environment Network, p. 1.

Prowse, M. 2003. Towards a clearer understanding of 'vulnerability' in relation to chronic poverty. CPRC Working Paper 24, University of Manchester, Chronic Poverty Research Center, Manchester, $41 \mathrm{pp}$.

Sabine L. Perch-Nielsen 2010. The vulnerability of beach tourism to climate change - an index approach. Climatic Change, 100: 579-606. DOI 10.1007/s10584-009-9692-1

UNPEI 2003. UNDP-UNEP-Poverty Environment initiative. Poverty and climate change: Reducing the vulnerability of the poor through adaptation. African DB; Asian DB; DFID; EC; Federal Ministry for Economic Cooperation and Development, Germany; Ministry of Foreign Affairs Development Cooperation, The Netherlands; OECD; UNDP; UNEP; The World Bank. http://www.unpei.org/sites/default/ files/publications/Poverty-and-Climate-Change.pdf

Wandiga Shem, O., Maggie Opondo, Daniel Olago, Andrew Githeko, Faith Githui, Michael Marshall, Tim Downs, Alfred Opere, Christopher Oludhe, Gilbert O. Ouma, Pius Z. Yanda, Richard Kangalawe, Robert Kabumbuli, James Kathuri, Eugene Apindi, Lydia Olaka, Laban Ogallo, Paul Mugambi, Rehema Sigalla, Robinah Nanyunja, Timothy Baguma and Pius Achola 2010. Vulnerability to epidemic malaria in the 
highlands of Lake Victoria basin: the role of climate change/ variability, hydrology and socio-economic factors. Climatic Change, 99: 473-497. DOI 10.1007/s10584-009-9670-7.
World Bank 2000. World Development Report 2000/2001, Published for the World Bank, Washington DC, Oxford University Press, New York, 200 pp. 